\title{
Periclimenes nevillei sp. nov. (Crustacea: Decapoda: Pontoniinae) from Vanuatu
}

\author{
A.J. BRUCE \\ Crustacea Section, Queensland Museum, P.O. Box 3300, South Brisbane, Queensland, 4101 Australia. E-mail: abruce@broad.net.au
}

\begin{abstract}
A new species of pontoniine shrimp, Periclimenes nevillei, from Espiritu Santo, Vanuatu, is described and illustrated. The species is an associate of an antipatharian host, Cirripathes sp. A member of the Periclimenes brevicarpalis species group, to which a key is provided, it most closely resembles Periclimenes albolineatus Bruce \& Coombes, 1997.
\end{abstract}

Key words: Caridea, Palaemonidae, new species, Antipatharia, commensal

\section{Introduction}

The pontoniine shrimp fauna of Vanuatu has been little studied and no such shrimps have so far been reported from its surrounding reefs. Recent photographic studies of the marine fauna of these coral reefs by Mr Neville Coleman, Curator of the Australian Marine Photographic Index, have revealed the presence of a species of Periclimenes in association with an antipatharian host, a whip coral, Cirripathes sp. No Periclimenes species have been reported in association with these, which are well known as hosts for other pontoniine shrimps such as Dasycaris zanzibarica Bruce, 1973 and Pontonides spp. (Bruce 1973; Marin 2007). Fortunately two specimens were collected, from hosts about $1.0 \mathrm{~m}$ apart. These could not be identified with any known species of the re-defined genus Periclimenes (Bruce 2007) and are now described as a new species of that genus. The specimens are deposited in the collections of the Queensland Museum, Brisbane.

Abbreviations used: AMPI, Australian Marine Photographic Index; CL, post-orbital carapace length; QM, Queensland Museum, Brisbane; R., rostral dentition, dorsal teeth/ventral teeth.

\section{Systematics}

Family Palaemonidae Rafinesque, 1815

Sub-family Pontoniinae Kingsley, 1879

Genus Periclimenes Costa, 1844

Periclimenes nevillei sp. nov.

(Figs 1-6)

Material examined. Ovigerous $q$ holotype, QM W28767, 1 ○े paratype, QM W28768, AMPI 1499, Espiritu Santo, Vanuatu, 8 m, coll. N. Coleman, September 2004.

Diagnosis. A small Periclimenes with rostrum well developed, straight, horizontal, with dorsal carina with 7 teeth, ventral carina with 2. Carapace without supraorbital spines, inferior orbital angle without reflected inner flange. Third abdominal segment not strongly postero-dorsally produced. Median ophthalmic process absent. Cornea well developed, globular. Fingers of first pereiopods simple, compressed. Second 
pereiopods well developed, subequal and similar, neither second pereiopod extremely elongate, palm smooth, fingers feebly dentate, distally entire, not proximally gaping, dactyls without lateral flange, merus without distoventral tooth. Ambulatory pereiopods with dactyl not long and slender, less than 0.25 of propod length. Telson with dorsal spines of normal size.

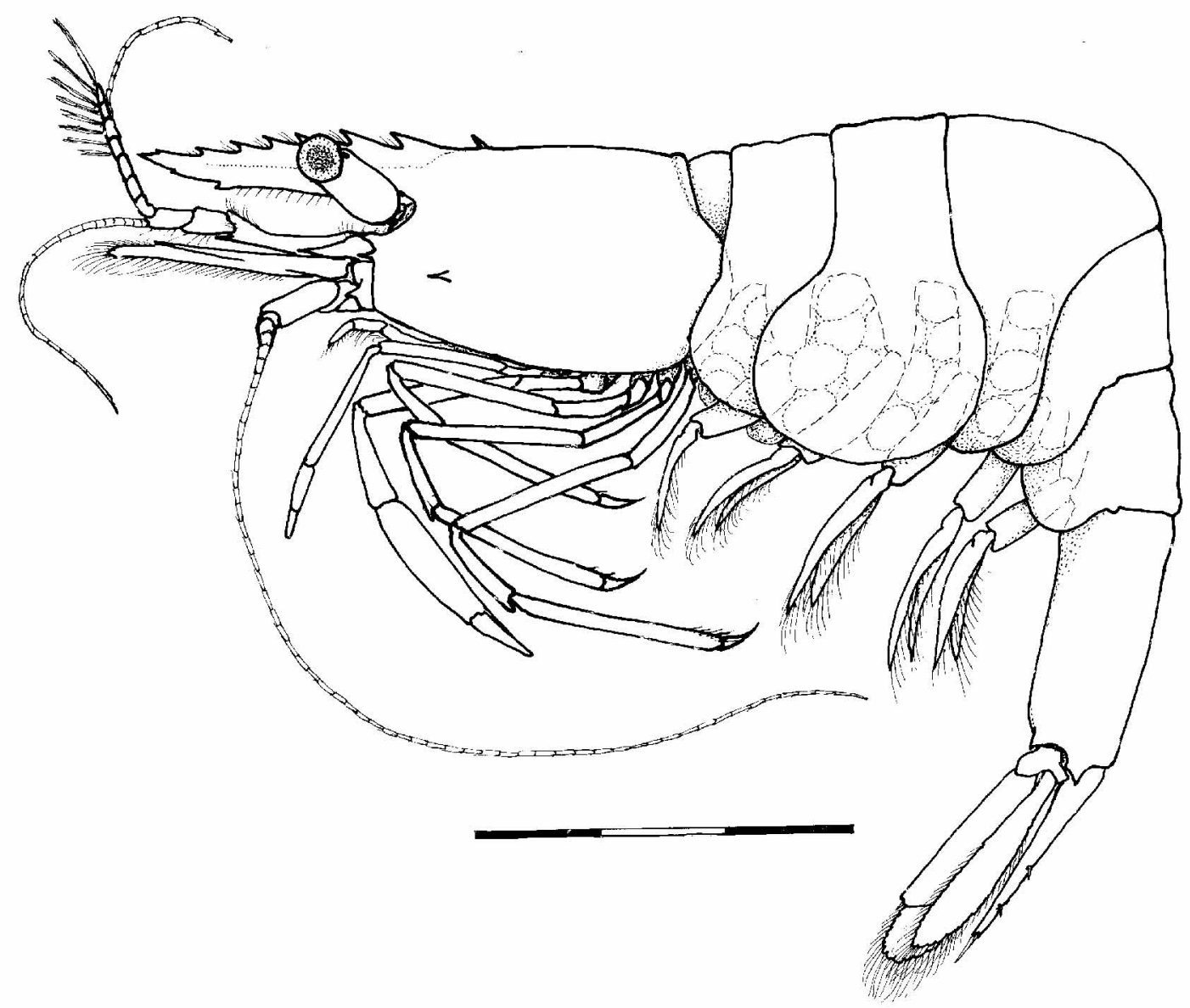

FIGURE 1. Periclimenes nevillei gen. nov., sp. nov., holotype female, Vanuatu, QM W28767. Scale bar in millimetres.

Description. A small sized pontoniine shrimp of subcylindrical body form.

Rostrum (female) (Fig. 2B) well developed, compressed, subequal to CL, acute, slightly exceeding antennular peduncle, 1.1 times CL, dorsal carina well developed, with 7 acute teeth, decreasing in size distally, with few interdental plumose setae, ventral carina obsolete, margin feebly convex, with 2 small acute teeth at about 0.67 and 0.85 of rostral length, with numerous short plumose median setae. (ð), rostrum (Fig. 4B) about 0.9 of CL, more slender, otherwise similar to female.

Carapace (Figs 2A, 4A) smooth, glabrous; with articulated epigastric spine at 0.19 of CL; without supraorbital spines or ridges; orbit obsolescent, inferior orbital angle (Fig. 5A) produced, subacute, angular, with dorsal hump, without ventral flange; antennal spine well developed, marginal, exceeding inferior orbital angle; hepatic spine similar to antennal, at slightly lower level, anterior to epigastric spine level; anterolateral angle obtusely rounded.

Abdominal segments smooth, third segment tergite not posteriorly produced, without posterior marginal denticulations; sixth segment subequal to CL, twice as long as fifth, 2.4 times longer than central depth, posteroventral and posterolateral angles similar, acute; pleura broadly rounded, expanded on first 3 segments.

Telson (Fig. 5K) about 0.8 of CL, 0.8 of sixth abdominal segment length, 4.0 times longer than anterior width; lateral margins sub-parallel anteriorly, convergent posteriorly, with 2 pairs of similar small submarginal dorsal spines, subequal to lateral posterior marginal spine length, at about 0.6 and 0.85 of telson length; 
posterior margin about 0.3 of anterior margin width, angular with central process without median point; posterior margin with lateral spines short, about 0.27 of intermediate spine length, intermediate spines long, about 0.15 of telson length, submedian spines shorter, about 0.4 of intermediate spine length, setulose.

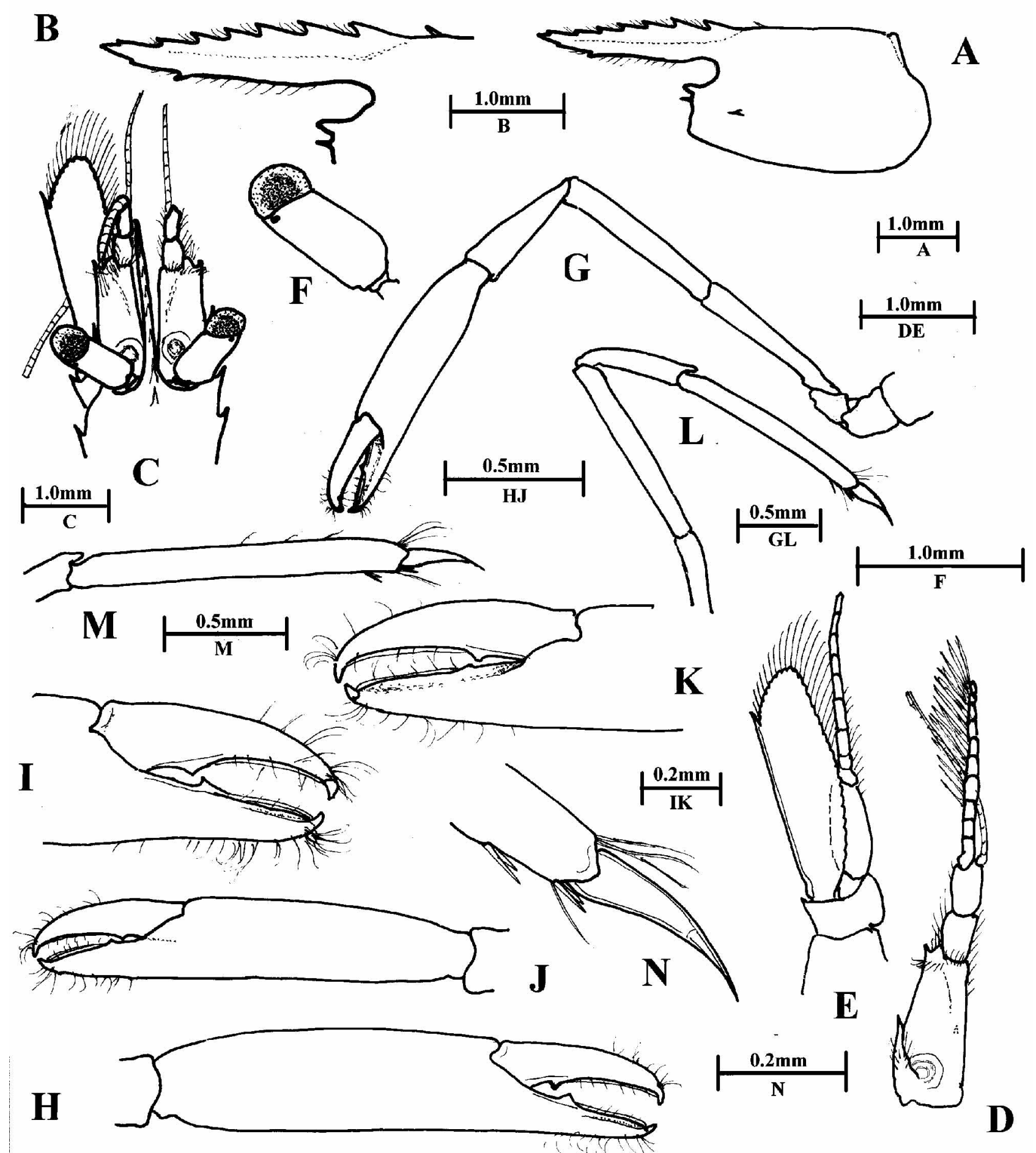

FIGURE 2. Periclimenes nevillei gen. nov., sp. nov., Vanuatu. A, carapace and rostrum. B, rostrum. C, anterior carapace, antennae and eyes, dorsal. D, antennule. E, antenna. F, eye, dorsal. G, major second pereiopod. H, same, chela. I, same, fingers. J, minor second pereiopod, chela. K, same, fingers. L, third pereiopod. M, same, propod and dactyyl. N, same, distal propod and dactyl. A-C, G-N, holotype female, QM W28767. D-F paratype male, QM W28768. 

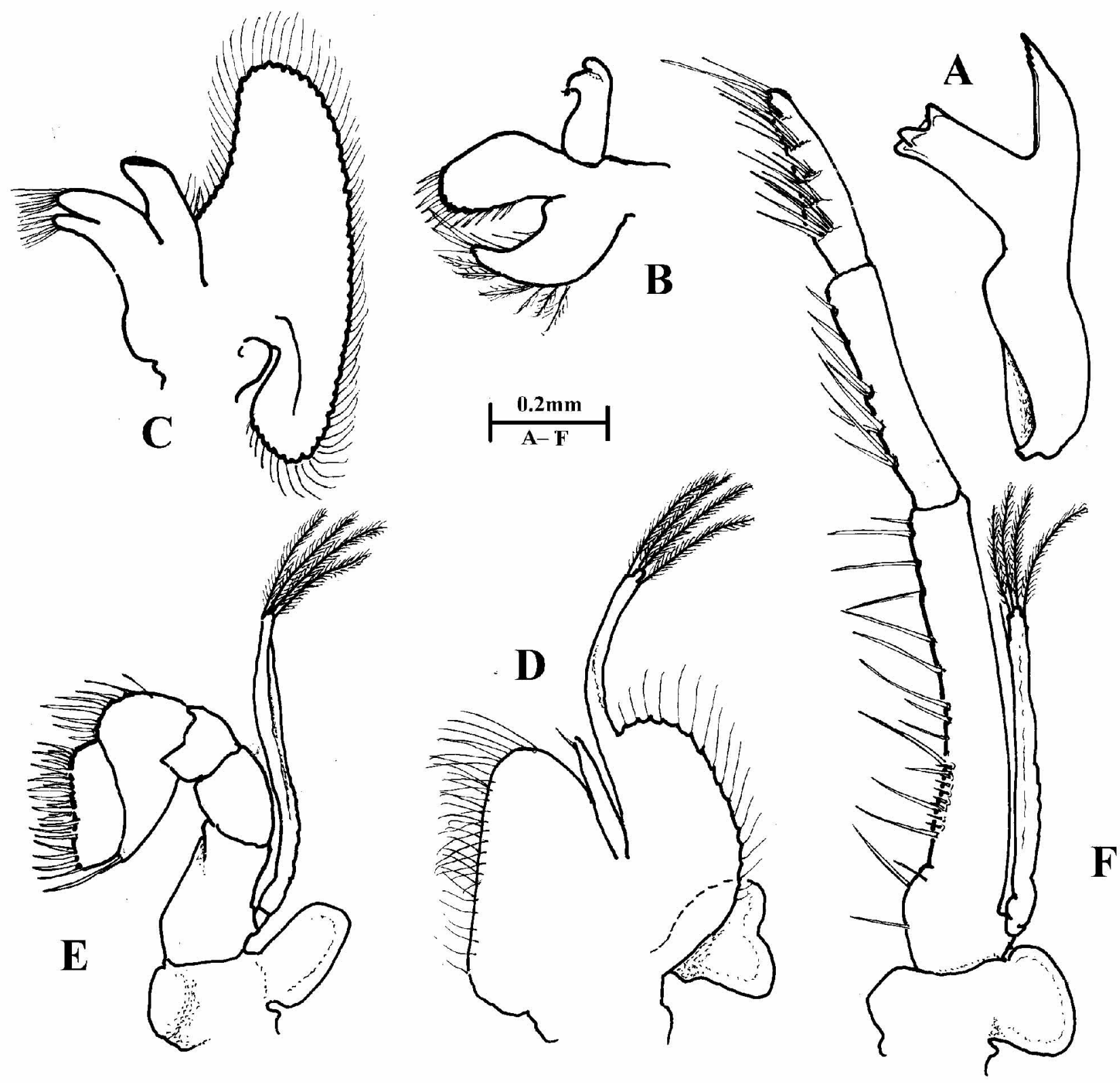

FIGURE 3. Periclimenes nevillei gen. nov., sp. nov., paratype male, Vanuatu, QM W28768. A, mandible. B, maxillula. C, maxilla. D, first maxilliped. E, second maxilliped. F, third maxilliped.

Antennule, female (Fig. 2C, D) with proximal segment about 2.4 times longer than central width, distal half tapering, medial margin setose with ventromedial tooth at half length, distolateral angle (Fig. 5B) medially angularly produced, with strong acute tooth laterally; stylocerite (Fig. 5C) slender, acute, reaching to about half segment length, dorsal surface with numerous long plumose setae; intermediate segment subequal to distal segment length, medial and lateral margins setose, distal segment non-setose; upper flagellum biramous, proximal 5 segments of rami fused, shorter free ramus with 2 segments, with 8 groups of aesthetascs, longer ramus filiform; lower flagellum filiform, both damaged. Male with upper rami fused for 6 segments, with 4 free segments, about 16 groups of aesthetascs.

Antenna(Fig. 2C, E) with robust basicerite with acute distolateral tooth, carpocerite about 2.4 times longer than central width, slightly swollen, reaching to about half scaphocerite length, flagellum well developed, scaphocerite extending well beyond antennular peduncle, lamella 3.7 times longer than central width, lateral margin straight with strong slender tooth at 0.85 of scaphocerite length, lamella distally bluntly angular. 

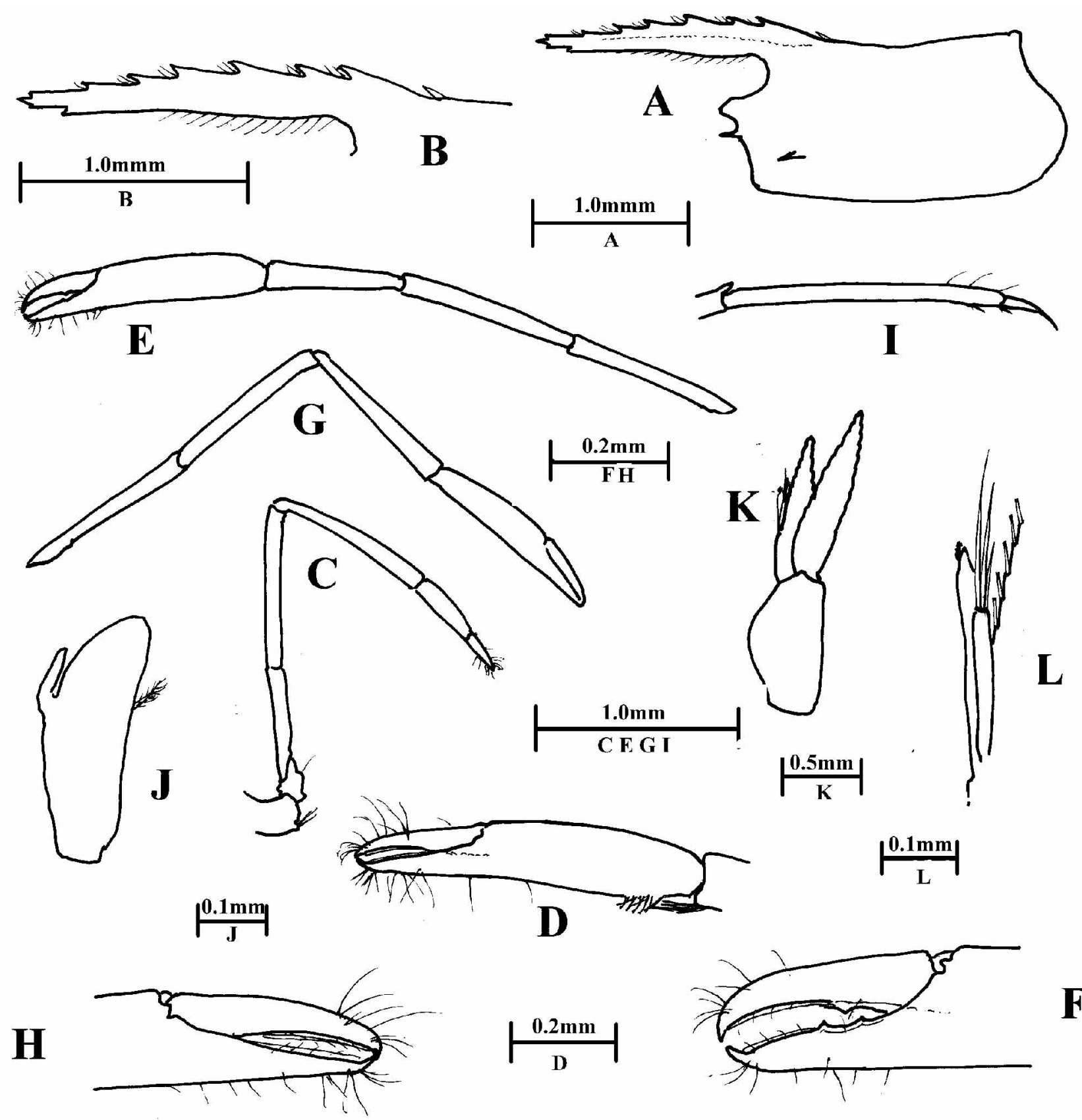

FIGURE 4. Periclimenes nevillei gen. nov., sp. nov., paratype male, Vanuatu, QM W28768. A. carapace and rostrum. B, rostrum. C, first pereiopod. D, same, chela. E, major second pereiopod. F, same, fingers. G, minor second pereiopod. $\mathrm{H}$, same, fingers. I, third pereiopod, propod and dactyl. J, first pleopod, endopod. K, second pleopod, L, same, appendices masculina and interna.

Epistome (Fig. 5D) with larger anterior and smaller posterior rounded submedian eminences.

Ophthalmic somite without median ophthalmic process or median pigment spot.

Eye (Fig. 2CF) with well developed, pigmented, globular cornea, with accessory pigment spot, diameter about 0.18 of CL; stalk subcylindrical, about 2.0 times longer than wide.

Thoracic sternites broad, increasing in width posteriorly, first, second and third maxillipeds widely separated, sternites unarmed, fourth without median process, fifth with low transverse ridges separated by median notch.

Mouthparts (male). Mandible (Fig. 3A) with corpus slender, without palp; molar processes (Fig. 5E, F) subcylindrical, distally truncate, with several subacute blunt marginal teeth, group of stout spiniform setae anteriorly, smaller tuft posteriorly; incisor process (Fig. 5G) slender, margins sub-parallel, distally oblique 
with 4 well developed acute teeth, central pair only slightly smaller than medial and lateral teeth. Maxillula (Fig. 3B) as usual for the genus; palp (Fig. 5H) distinctly bilobed, lower lobe stouter, with small ventral tubercle bearing minute seta; upper lacinia (Fig. 5I) expanded centrally, tapering distally, distal margin rounded with about 8 short stout simple spines with more slender setae; lower lacinia curved, tapering distally, with 4 stout spiniform terminal setae, numerous slender simple setae distally and marginally. Maxilla (Fig. 3C) with simple tapering palp, about 3.0 times longer than basal width, with 2 short plumose setae proximolaterally; basal endite bilobed, distal lobe with 8 simple setae distally, more robust than similarly setose proximal lobe; coxal endite obsolescent, convex, non-setose; scaphocerite well developed, about 2.6 times longer than central width, anterior lobe with medial margin concave, distally rounded, posterior lobe about 0.6 of anterior lobe length. First maxilliped (Fig. 3D) with slender palp, about 6.5 times longer than basal width, with short simple preterminal seta; basal and coxal endites completely fused, broad, 2.0 times longer than wide, distal margin rounded with sparse long simple setae, medial margin straight with numerous shorter spiniform setae, proximally rounded non-setose; exopod well developed with slender flagellum with 4 plumose terminal setae, caridean lobe about 2.5 times longer than central width; epipod small, feebly bilobed, cordiform. Second maxilliped (Fig. 3E) of usual form for the genus, endopod with dactylar segment about 2.5 times longer than broad, with numerous stout denticulate spines medially, propodal segment distally rounded, not medially produced, with several long simple marginal spiniform setae; carpus, ischiomerus and basis without special features; exopod with slender flagellum with 4 plumose terminal setae; coxa with rounded non-setose medial boss; epipod small, suboval, without podobranch. Third maxilliped (Fig. 3F) with endopod slender, reaching to about proximal end of carpocerite; ischiomerus and basis fully fused, junction feebly indicated medially, combined segment about 8.5 times longer than central width, basal region expanded, medially convex, sparsely setose, ischiomerus with numerous long simple spiniform setae medially, laterally non-setose, with submarginal ventral row of 8 very short setae on proximal medial region of ischiomerus; penultimate segment about 0.5 of proximal segment, uniform, with 8 long simple spiniform setae and few simple setae medially, subcylindrical, 5.0 times longer than wide; terminal segment 0.4 of proximal segment length, 4.0 times longer than wide, slightly swollen proximally, tapering distally with about 5 or 6 transverse rows of denticulate setae medially; exopod with slender flagellum reaching to about 0.75 of proximal endopod segment length, with 4 long plumose terminal setae; coxa medially produced, rounded, non-setose, lateral plate well developed, rounded, without arthrobranch (possibly lost in dissection).

First pereiopod (Fig. 4C) slender, reaching to about middle segment of antennular peduncle, slender, chela (Fig. 4D) with palm about 3.4 times longer than central depth, oval in section, with several rows of short pectinate spines proximo-medially, fingers about 0.6 of palm length, slender simple, with small, hooked tips, distal cutting edges laminar, entire; carpus 1.5 times chela length, about 8.0 times longer than distal width, with several longer pectinate spines distomedially; merus slender, subequal to carpus length, 1.5 times ischium length, basis normal; coxa with small rounded distoventral process with 3 simple spiniform terminal setae.

Second pereiopods. In female (Fig. 2G), slightly unequal, similar. Major chela (Fig. 2H) exceeding antennular peduncle by dactyl, chela about 0.75 of CL, palm smooth, uniform, oval in section, about 3.2 times longer than depth, dactyl (Fig. 2I) about 0.5 of palm length, robust, 3.5 times longer than proximal depth, dorsal margin convex, strongly hooked unguis distally, cutting edge straight, distal half sharp, entire, with single small acute tooth at 0.3 of length, with scattered setae, fixed finger (Fig. 2I) 2.0 times longer than proximal depth, slightly spatulate distally, otherwise similar to dactyl, with single small acute tooth at about 0.5 of length, carpus about 0.66 of palm length, 3.3 times longer than distal width, distally unarmed, tapering proximally, merus 0.95 of palm length, 6.2 times longer than wide, ischium 0.87 of palm length. Minor chela (Fig. 2JK) reaching to end of antennular peduncle, about 0.86 of major chela length, similar to major chela, segments slightly shorter and more slender.

In male (Fig. 4E), slightly unequal, major chela about 0.7 of CL, palm smooth, subcylindrical, oval in section, slightly swollen centrally, about 4.0 times longer than central depth, fingers (Fig. 4F) about 0.5 of palm length, dactylus slender, compressed, about 4.0 times longer than proximal depth, tip curved with strong hooked terminal tooth, cutting edge with small blunt slightly recurved tooth at mid-length, distal cutting edge 
laminar, entire, fixed finger 2.4 times longer than proximal depth, similar to dactyl but with 2 small acute teeth centrally, opposite dactylar tooth, with small depression; carpus 0.7 of palm length, 4.5 times longer than distal width, tapering proximally, unarmed; merus slender, subequal to palm length, uniform, 9.0 times longer than wide, unarmed; subequal to merus length, slender, 12.5 times longer than central width, unarmed; basis and coxa without special features. Minor second pereiopod (Fig. 4G) with chela 0.78 of major chela length, palm 4.0 times longer than distal width, oval in section, tapering slightly proximally, fingers (Fig. $4 \mathrm{H}$ ) 0.6 of palm length, slender, simple, with strongly hooked tips, dactyl 4.2 times longer than proximal width, cutting edge unarmed, distally laminar, fixed finger similar; carpus 1.35 times palm length, slender, 8.0 times longer than distal width; merus subequal to carpal length, ischium subequal to carpus length.

Ambulatory pereiopods slender, third pereiopod (Figs 2L, 4I) with dactyl (Figs 2N, 5J) about 0.2 of propod length, slender, about 4.0 times longer than basal width, simple, curved, with unguis poorly demarcated, about 0.75 of corpus length; propod (Fig. 2M) about 0.65 of CL, 10.0 times longer than wide, with pair of short distoventral spines and pair of similar distal ventral spines, carpus half of propod length, merus subequal to propod length, ischium subequal to carpal length; fourth pereiopod similar to third, propod 1.15 times longer, with single distoventral and distal spines; fifth pereiopod 1.22 times longer than third, distally with numerous spiniform setae only.

Pleopods as usual in the genus. Male first pleopod with endopod (Fig. 4J) about 3.2 times longer than wide, distally rounded, non-setose, with well developed medial accessory lobe. Second pleopod (Fig. 4K) with appendices (Fig. 4L) well developed, arising at 0.3 of proximal margin length, appendix masculina corpus about 7.5 times longer than wide, 0.27 of ramus length, with 2 long and 1 shorter simple terminal spiniform setae, longest spine greater than corpus length; appendix interna slender, 1.5 times length of appendix masculina, with few terminal cincinnuli.

Uropods (Fig. 5K) as usual in the genus, protopodite postero-laterally unarmed; exopod about 3.8 times longer than wide, extending well beyond endopod, lateral margin straight, with short submarginal setae ventrally, ending in small acute tooth with much larger mobile spine medially (Fig. $5 \mathrm{~N}$ ), with well developed complete diaeresis (Fig. 5M) and large oval terminal lamina; endopod 0.8 of exopod length, about 4.0 times longer than wide, exceeding tips of posterior telson spines.

Measurements. Holotype female, postorbital carapace length, $2.3 \mathrm{~mm}$; carapace and rostrum, $4.5 \mathrm{~mm}$; total body length, $14.0 \mathrm{~mm}$; major second pereiopod chela, $1.75 \mathrm{~mm}$; minor second pereiopod chela, $1.6 \mathrm{~mm}$; length of ovum, $0.5 \mathrm{~mm}$. Paratype male, postorbital carapace length, $2.3 \mathrm{~mm}$; carapace and rostrum, $4.5 \mathrm{~mm}$; total body length, $14.0 \mathrm{~mm}$; major second pereiopod chela, $1.4 \mathrm{~mm}$; minor second pereiopod chela, $1.2 \mathrm{~mm}$.

Etymology. Named in honour of the collector, Neville Coleman, Curator of the Australian Marine Photographic Index.

Host. Cirripathes sp. [Antipathidae, Antipatharia].

Colouration. (From colour photo, Fig. 6). Body mainly semi-transparent, densely speckled with small yellowish-white patches; antennae and ambulatory pereiopods similar; cornea and ophthalmic somite white; eyestalk with two longitudinal white lines dorsally; hepatopancreas olive speckled with red, ovary similar, heavily marked with white; first 3 abdominal segments ventrally reddish; dorsal surface of second and third segments with transverse white bar, similar smaller narrower bars on fourth and fifth segments; caudal fan proximally white, exopod and endopod distally white.

Systematic position. Periclimenes nevillei sp. nov. is morphologically most similar to P. albolineatus Bruce \& Coombes, 1997, from which it may be distinguished by its longer rostrum (dentition $1+6 / 2$ ) exceeding the antennular peduncle, with two distal ventral teeth (versus $1+4-5 / 0$, shorter than antennular peduncle); inferior orbital angle strongly produced (versus feebly produced); fingers of second pereiopods not distally gaping, fixed finger with single tooth (versus fingers of second pereiopods distally gaping, fixed finger with two teeth); carpus 0.6 of palm length (versus 0.3 ); ambulatory propod slender, with distal and distoventral spines, sparsely setose (versus robust, non-spinose, with long setae); dactyl slender, about 02 of propod length, not strongly curved (versus robust, dactyl about 0.25 of propod length, strongly curved); uropodal exopod with very small distolateral tooth (versus with well developed tooth), 
Remarks. Numerous popular field guides to the tropical marine life of the Indo-West Pacific region provide illustrations of Cirripathes spp. and the pontoniine and pandalid shrimps associated with these hosts, particularly Dasycaris zanzibarica Bruce, 1973, Pontonides spp., and Miropandalus hardingi Bruce, 1983. Several of these species have a similar colour pattern to the host consisting of conspicuous broad transverse yellow bands, quite distinct from the colouration of $P$. nevillei. That this new species has not been previously observed or collected suggests that it may be relatively rare or of limited distribution.
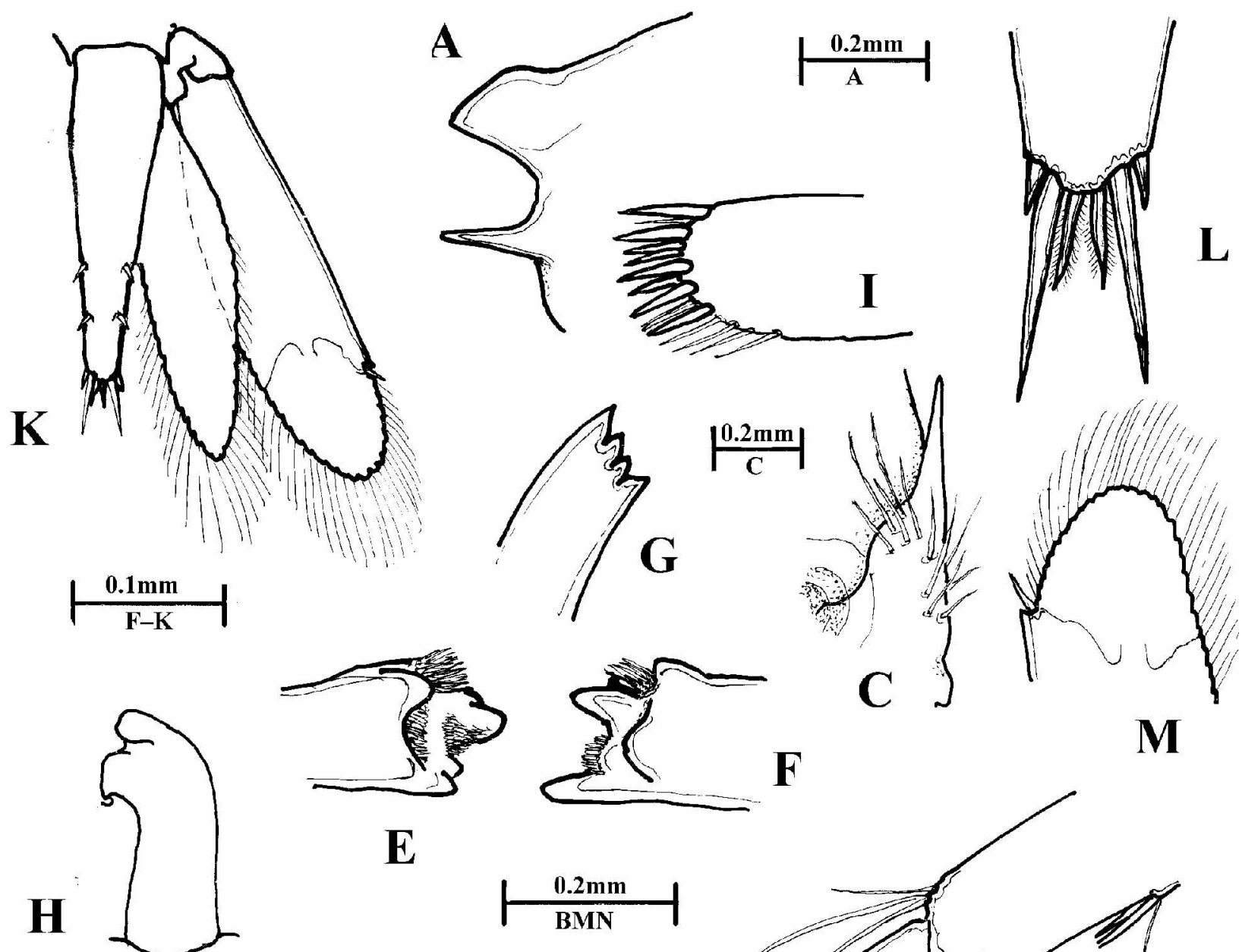

M
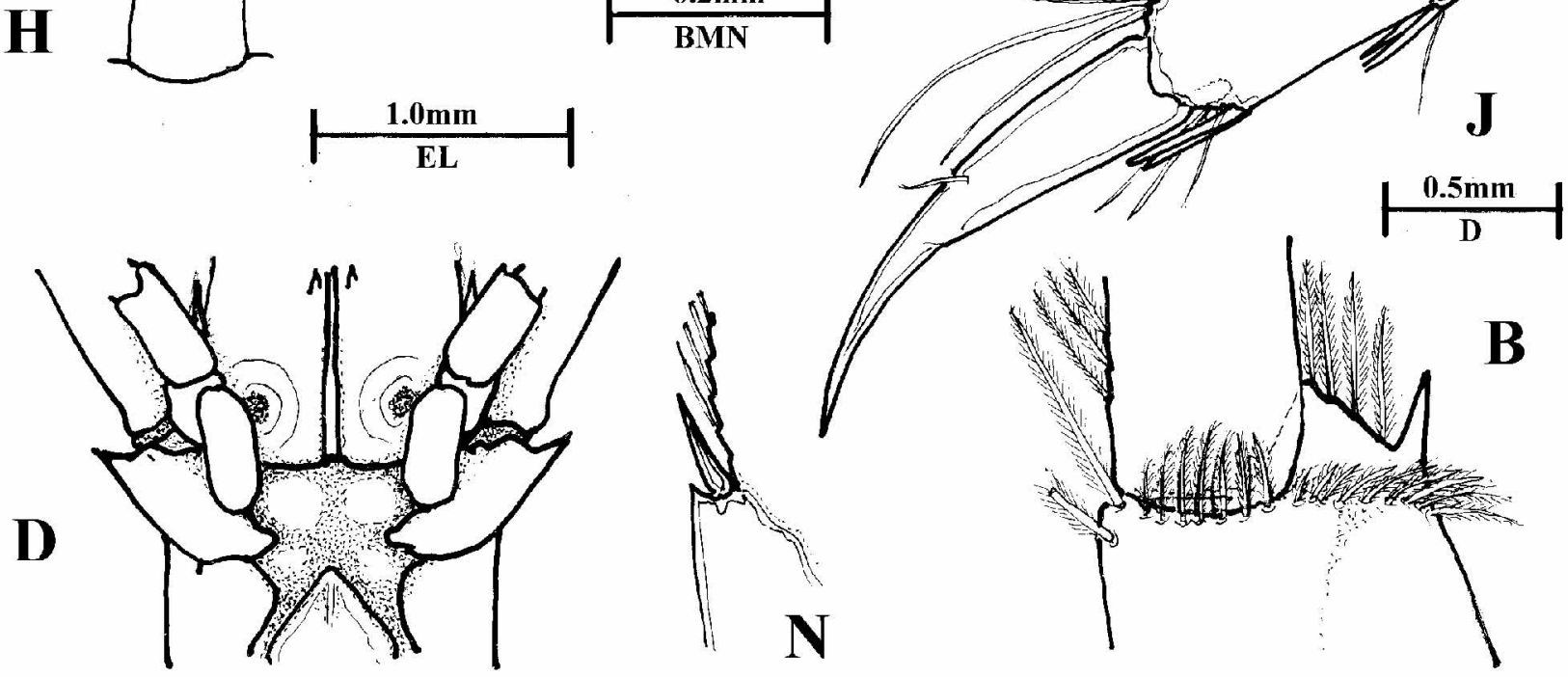

FIGURE 5. Periclimenes nevillei gen. nov., sp. nov., Vanuatu A, inferior orbital angle. B, antennule, proximal segment, distolateral angle. C, same, stylocerite. D, scaphocerite, distal lamella. D, epistomal region. E, mandible, molar process. F, same, G, same, incisor process. H, maxillula, palp. I, same, upper lacinia. J. third pereiopod, distal propod and dactyl. $\mathrm{K}$, telson and right uropod. L, telson, posterior marginal spines. M. uropod, posterior. N, same, distolateral angle. C-E, $\mathrm{K}$, holotype female, QM W28767. A-B, F-N, paratype male, QM W28768. 


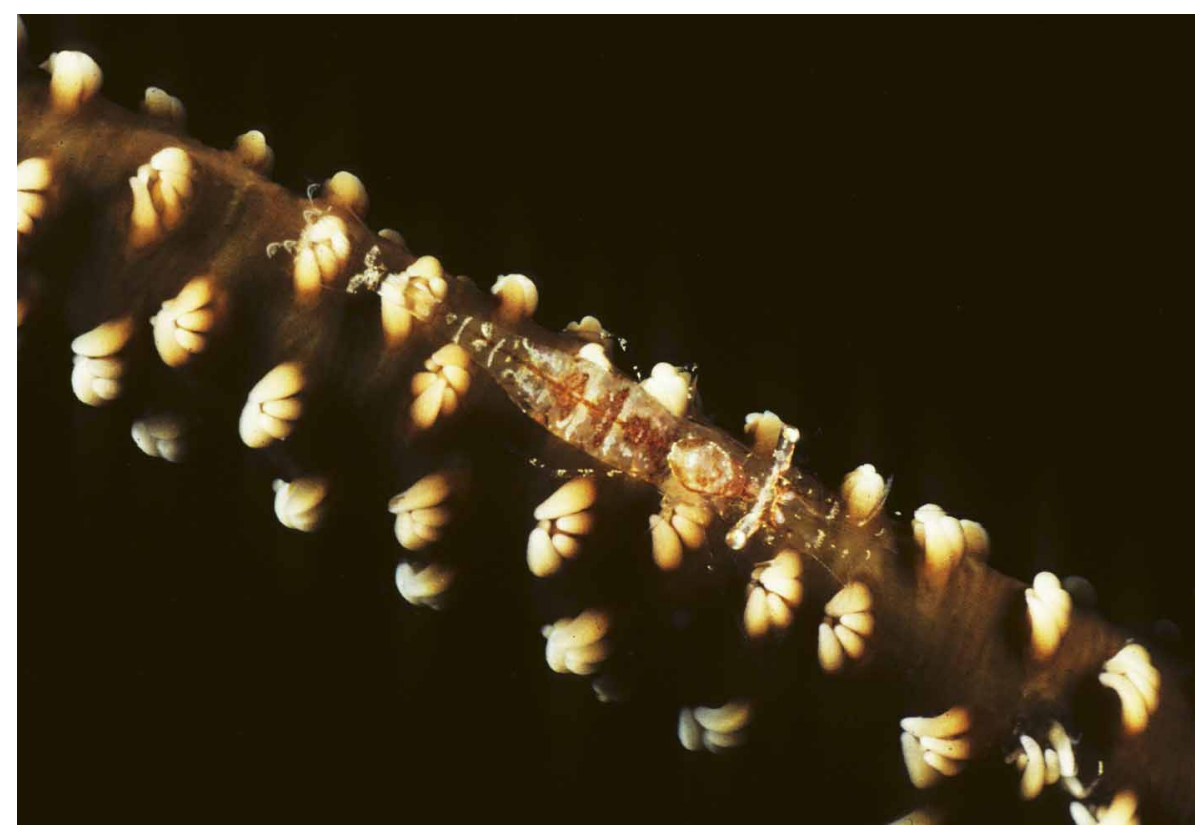

FIGURE 6. Periclimenes nevillei gen. nov., sp. nov., holotype female, Vanuatu, QM W28767, on Cirripathes sp., photograph by Neville Coleman.

\section{Discussion}

Periclimenes nevillei may be considered a further member of the brevicarpalis species group (Bruce \& Coombes 1997). All are associates of coelenterates, mainly actinarians. Only P. nevillei is known to associate with antipatharians. This group is characterized by the following features.

\section{Periclimenes brevicarpalis species group}

Rostrum well developed, straight, horizontal, with dentate dorsal carina. Carapace without supraorbital spines; inferior orbital angle without reflected inner flange. Third abdominal segment not strongly posterodorsally produced. Median ophthalmic process absent. Cornea well developed, globular. Fingers of first pereiopods simple. Second pereiopods well developed, subequal and similar, neither second pereiopod extremely elongate, palm non-tuberculate, fingers feebly dentate, distally entire, dactyls without lateral flange, merus without distoventral tooth. Dactyl of ambulatory pereiopods simple, not long and slender, less than 0.25 of propod length.

\section{The following key enables the six Indo-West Pacific species of the brevicarpalis group to be distin- guished.}

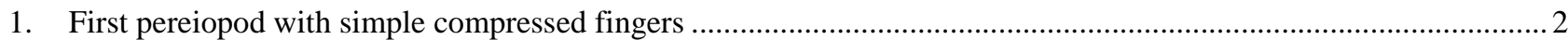

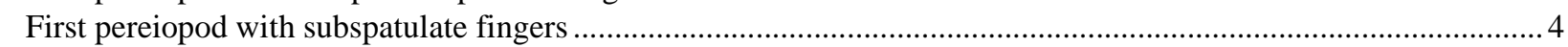

2. Dorsal telson spines minute; R. 5-7/1-2 ........................................................... P. brevicarpalis (Schenkel, 1902)

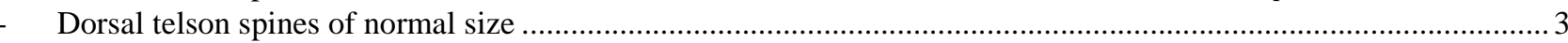

3. Rostrum shorter, 0.55 of CL, fingers of second pereiopods distally gaping; ambulatory propods non-spinulose, R. $1+4-5 / 0$ P. albolineatus Bruce \& Coombes, 1997

- $\quad$ Rostrum longer, subequal to CL, fingers of second pereiopods not distally gaping; ambulatory propods spinulose, R. $1+7 / 2$. P. nevillei sp. nov.

4. Dactyls of ambulatory pereiopods minutely spinulate around base of unguis; R. 7-10/1-2 
- Dactyls of ambulatory pereiopods with simple unguis

5. Fourth thoracic sternite with broad low transverse ridge, with open median notch; R. 7-8/0-1

P. inornatus Kemp, 1922

- $\quad$ Fourth thoracic sternite with centrally elongated transverse ridge, with deep closed median notch; R. 7/1

P. ornatus Bruce, 1969

\section{Acknowledgements}

I am most grateful to the collector, Neville Coleman, Curator of the Australian Marine Photographic Index, for the opportunity to examine these interesting specimens and for the use of his photograph.

This study was facilitated by support from the Australian Biological Resources Study.

\section{References}

Bruce, A.J. (1973) Notes on some Indo-Pacific Pontoniinae, XXIV. Dasycaris zanzibarica sp. nov., from the western Indian Ocean, with remarks on other species of Dasycaris Kemp, 1922 (Decapoda Natantia). Crustaceana, 24(3), 247-260.

Bruce, A.J. (1983) Miropandalus hardingi, new genus, new species, a bizarre commensal pandalid shrimp from the Marshall Islands. Journal of Crustacean Biology, 3(3): 482-490, figs. 1-5.

Bruce, A.J. (2007) A re-definition of the genus Periclimenes Costa 1844, and the designation of a new genus Margitonia (Crustacea: Decapoda: Pontoniinae). Cahiers de Biologie Marine, 48(4), 403-406.

Bruce, A.J. \& Coombes, K.E. (1997) An annotated check-list of the caridean shrimps (Crustacea: Decapoda) of Darwin Harbour, with descriptions of three new species of Periclimenes (Palaemonidae: Pontoniinae). In: Hanley, J.R., Caswell, G., Megirian, D. \& Larson, H.K. (eds.). Proceedings of the Sixth International Marine Biological Workshop. The Marine flora and fauna of Darwin Harbour, Northern Territory, Australia. Museums and Art Galleries of the Northern Territory and the Australian Marine Sciences Association, Darwin, Australia, 1997: 301337.

Marin, I. (2007) The coral-associated shrimp genus Pontonides (Caridea, Palaemonidae, Pontoniinae) in Nhatrang Bay, Vietnam, with description of two new. Zootaxa, 1653,1-21. 